\title{
Effect of Blossom \\ Thinners on Fruit Set and Fruit Size of Peaches
}

\author{
Duane W. Greene, ${ }^{1}$ \\ Karen I. Hauschild, ${ }^{2}$ and \\ James Krupa ${ }^{3}$
}

Additional Index wOrds. peach thin-
ning, ammonium thiosulfate,
endothall, Wilthin, hand thinning,
ATS, Prunus persica, fruit abscission

Summary. Endothall (mono-N,Ndimethylalkylamine salt, $15.9 \%$, endothallic acid $3.8 \%$ ), ammonium thiosulfate (ATS, 55\%), and Wilthin (1-aminomethanamide dihydrogen tetraoxosulfate, $79 \%$ ) were evaluated over 3 years for use as blossom thinners on mature 'Garnet Beauty' and 'Red Haven' peaches (Prunus persica). Endothall and ATS were the most effective blossom thinners and reduced set in all 3 years. Wilthin reduced initial set in 2 of 3 years. Hand thinning was reduced by $50 \%$ to $80 \%$ on endothall and ATS treated trees. The reduction in crop load at bloom resulted in significant increases in fruit size at harvest. We suggest the use of ATS at a rate of 35 to $45 \mathrm{Lha}^{-1}$ (3.5 to $5 \mathrm{gal} / \mathrm{acre}$ ) and endothall at 1.8 $\mathrm{L}^{-1} \mathrm{ha}^{-1}$ (1.5 pt/acre), applied in 935 $\mathrm{L} \mathrm{ha}^{-1}$ (100 gal/acre) on mature trees. The use of Wilthin at rates higher than 18.6 $\mathrm{L}^{-h^{-1}}$ (8 qt/acre) may be required for adequate thinning, but phytotoxicity at higher rates was not tested. Other important components for successful blossom thinning include applying materials before the majority of flowers have been pollinated (slightly before full bloom) and to apply the spray when there is very little

This material is based upon work supported by the Cooperative State Research Extension Education Ser vice, U.S. Department of Agriculture, Massachusetts Agriculture Experiment Station, as journal paper 3273 under project 747 . The cost of publishing this paper was defrayed in part by the payment of page charges. Under postal regulations, this paper therefore must be hereby marked advertisement solely to indicate this fact.

${ }^{1}$ Professor, Department of Plant and Soil Sciences, Bowditch Hall, University of Massachusetts, Amherst, MA 01003.

${ }^{2}$ Extension specialist (retired), Plant \& Soil Sciences, University of Massachusetts, Horticultural Research Center, Belchertown, MA 01007.

${ }^{3}$ Senior technical assistant, University of Massachusetts, Horticultural Research Center, Belchertown, MA01007. 
wind to assure good coverage and to prevent localized areas displaying increased phytotoxicity.

$M$ ost fruit thinning on apples is accomplished with chemicals that are applied after bloom. They cause thinning by either affecting hormone content or by influencing carbohydrate distribution among rapidly developing fruit. Blossom thinner application may precede postbloom thinners so that less aggressive postbloom thinning would be required. Unfortunately, all postbloom hormone-type thinners are ineffective on peaches. Therefore, the only effective method to chemically reduce fruit load on peaches is to apply a caustic thinner during bloom.

In recent years several compounds, when applied at bloom, have been reported to be effective at reducing crop load on peaches (Byers, 1999; Byers and Lyons, 1985; Fallahi, 1997). Compounds most frequently evaluated are endothall, pelargonic acid, sulfcarbamide, ammonium thiosulfate, and hydrogen cyanamide (Byers, 1999; Byers and Lyons, 1984; Fallahi, 1997). There are several reasons why blossom thinner use on peaches has not been universally accepted. Some thinners have not been registered for use on fruit crops, results reported have been erratic and inconsistent, and there is a reluctance by growers to apply chemicals designed specifically to reduce fruit set before a crop has been set, and initial crop load could be assessed.

Apples have been the primary crop grown by orchardists in New England, but this focus is changing due to global competition and low apple prices that has forced growers to consider diversification. Increasingly, growers are decreasing their dependence on apples, reducing total acreage, and diversifying into other crops, especially peaches (Lord, 1999). Peaches can be a very lucrative crop if large-sized fruit are produced. Most peaches require hand thinning for fruit to reach optimal size, and labor requirements for hand thinning of peaches frequently coincides with cultural demands required to successfully grow apples. Therefore, there is intense grower interest in using blossom thinners to increase fruit size and to reduce the amount of time and labor required to hand thin.

The purpose of this investigation was to evaluate the most promising blossom thinners so as to increase fruit size and to reduce the amount of hand thinning of peaches. We also hoped to identify appropriate concentrations to recommend to commercial growers, and to evaluate the consistency of response to chemical thinners.

\section{Methods and methods}

Mature 'Garnet Beauty' and 'Red Haven' trees growing at the University of Massachusetts Horticultural Research Center in Belchertown, Mass. were used in this investigation. Tree spacing was $5.2 \times 7.9 \mathrm{~m}(17 \times 24 \mathrm{ft})$, giving a density of 264 trees/ha (107 trees/acre). In each year 18 'Red Haven' trees and 24 'Garnet Beauty' trees were blocked into three groups (replications) and four groups (replications), respectively, of six trees each. Within each replication, trees were randomly assigned one of six treatments; control, two rates ofWilthin (Entek Corp., Brea, Calif.), two rates of Thinset (National Chelating Co., Orange, Calif.), and one rate of endothall(ElfAtochem, Philadelphia, Pa.).

1997 Experiment. Before the application of blossom thinners three limbs on each tree, 10 to $12 \mathrm{~cm}$ ( 3.9 to 4.7 inches) in circumference, were tagged and measured. Treatments were applied when $90 \%$ to $95 \%$ of the blossoms were open on 8 May, using a rear mounted airblast sprayer in $935 \mathrm{~L} \cdot \mathrm{ha}^{-1}$ of water. Wilthin was applied at rates of 9.3 and $14.0 \mathrm{~L} \cdot \mathrm{ha}^{-1}$ (4 and $6 \mathrm{qt} / \mathrm{acre}$ ) with $1.2 \mathrm{~L} \cdot \mathrm{ha}^{-1}$ (l pt/acre) Regulaid, a commonly used surfactant (Kalo Inc., Overland Park, Kan.), ATS was applied at 37.4 and $74.8 \mathrm{~L} \cdot \mathrm{ha}^{-1}$ (4 and 8 gal/acre), and the rate of endothall used was $1.5 \mathrm{~L} \cdot \mathrm{ha}^{-1}$ (1.25 pt/acre). Temperature the day of application did not exceed $16{ }^{\circ} \mathrm{C}\left(60^{\circ} \mathrm{F}\right)$, and wind at the time of application was blowing 25 to $35 \mathrm{~km} \cdot \mathrm{h}^{-1}$ (15 to 20 miles/h). One tree in each block was unsprayed and served as the control. All persisting fruit on tagged limbs were counted at the normal time for hand thinning, about $45 \mathrm{~d}$ after bloom, when fruit diameter averaged $2.5 \mathrm{~cm}$ ( 1 inch). Fruit were hand thinned to a commercially acceptable level on each limb, by spacing fruit to about $15 \mathrm{~cm}$ (6 inches) apart. The number of fruit hand thinned from each tagged limb was counted and that number was recorded. Fruit set, hand thinned fruit, and final set were calculated based upon the cross sectional area of each limb. Ten fruit or the number ready for commercial harvest were sampled from the tagged limbs on 31 July, 4 Aug., and 8 Aug. for 'Garnet Beauty', and on 12, 15, and 19 Aug. for 'Red Haven'. Harvested fruit were taken to the laboratory where they were weighed, the average fruit weight calculated, and then the diameter of each fruit measured with a hand-held fruit sizer.

1998 Experiment. Treatments in each block were assigned, limbs in each tree were selected, and treatments were applied similar to that described for 1997. Treatments were applied on 22 Apr., when the bloom on each variety was about $90 \%$ open. Wilthin was applied again at 9.3 and $14.0 \mathrm{~L} \cdot \mathrm{ha}^{-1}$ with $\mathrm{l} .2 \mathrm{~L} \cdot \mathrm{ha}^{-1}$ and endothall was applied at $1.5 \mathrm{~L} \cdot \mathrm{ha}^{-1}$. ATS was applied at 28.1 and $37.4 \mathrm{~L} \cdot \mathrm{ha}^{-1}$ and one tree per block was untreated. Temperature at the time of application was $21^{\circ} \mathrm{C}(70$ ${ }^{\circ} \mathrm{F}$ ) with a 3 to $4 \mathrm{~km} \cdot \mathrm{h}^{-1}$ ( 2 to 3 miles/ h) breeze. 'Garnet Beauty' was harvested at the normal commercial time on 21,24 , and 28 July, while 'Red Haven' was harvested on 4,6 , and 10 Aug. Harvest and evaluation of fruit were done as described in the 1997 experiment.

1999 EXPeriment. Treatments in each block were assigned, limbs in each tree were selected, and treatments were applied as was described in the 1997 experiment. Treatments were applied on 2 May when bloom on 'Garnet Beauty' was estimated to be $60 \%$ open while that on 'Red Haven' was judged to be $80 \%$ open. Wilthin was applied at 14.0 and $18.6 \mathrm{~L} \cdot \mathrm{ha}^{-1}$ with $1.2 \mathrm{~L} \cdot \mathrm{ha}^{-1}$ Regulaid, and endothall was applied at $1.8 \mathrm{~L} \cdot \mathrm{ha}^{-1}$. ATS was applied at 37.4 and $56.1 \mathrm{~L} \cdot \mathrm{ha}^{-1}$, and one tree per block was left unsprayed. 'Garnet Beauty' was harvested at the normal commercial time on 23,27 , and 30 July, while 'Red Haven' was harvested on 5, 10, and 12 Aug. Harvest and evaluation of fruit was done as described in the 1997 experiment.

\section{Results}

1997 EXPERIMENT. All three blossom thinners significantly reduced initial set which resulted in need to hand thin off fewer peaches at hand thinning time (Table 1). Only ATS reduced the final set after hand thinning was done. Endothall and ATS increased fruit weight and diameter at harvest, 
Table 1. Effect of Wilthin, ${ }^{\mathrm{z}}$ endothall, and ammonium thiosulfate (ATS) on fruit set, thinning, and fruit size of 'Garnet Beauty' and 'Red Haven' peaches, $1997(28.35 \mathrm{~g}=1.0 \mathrm{oz}, 2.54 \mathrm{~cm}=1.0$ inch $)$.

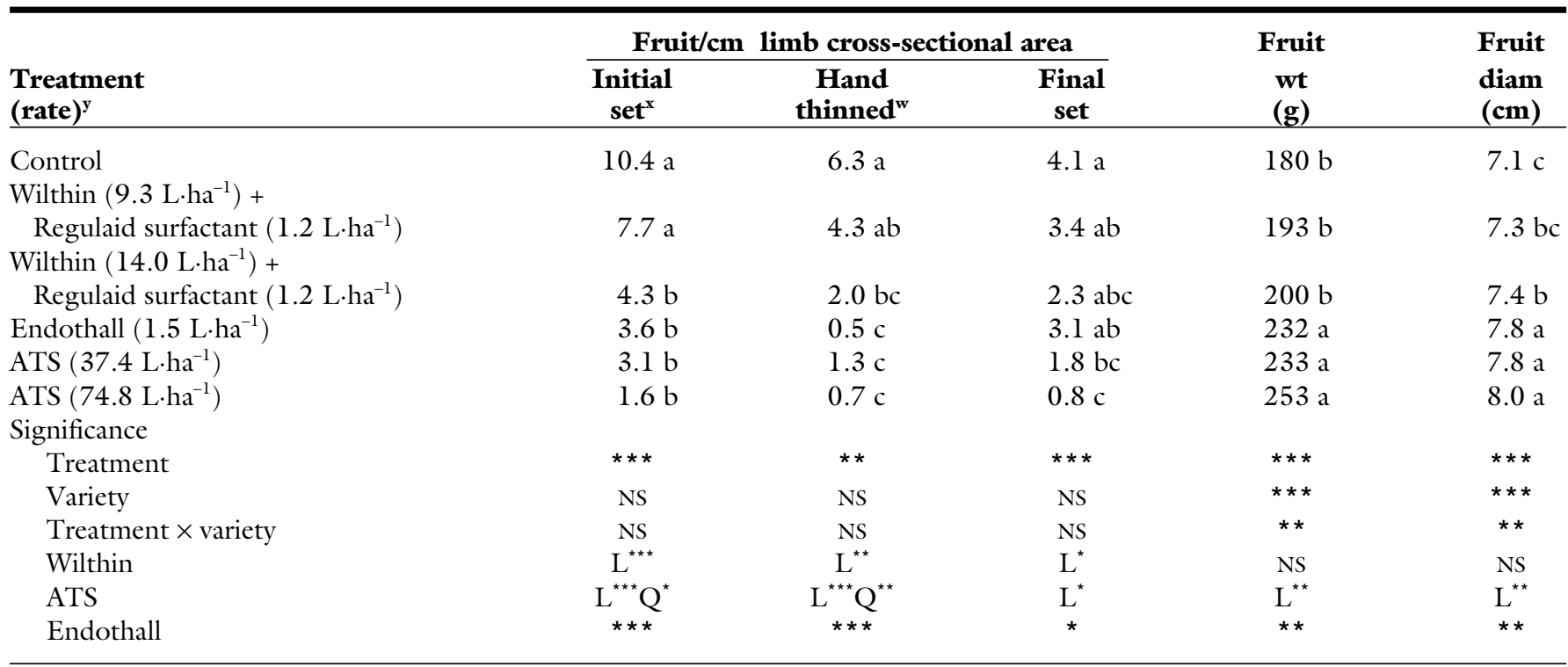

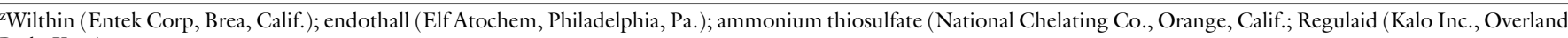
Park, Kan.).

'Treatments applied 8 May 1997 when flowers were $90 \%$ to $95 \%$ open. All treatments applied in $935 \mathrm{~L} \cdot \mathrm{ha}^{-1}(100 \mathrm{gal} / \mathrm{acre})$ of water; $9.35 \mathrm{~L} \cdot \mathrm{ha} \mathrm{a}^{-1}=1.0 \mathrm{gal} / \mathrm{acre}$.

${ }^{x}$ Mean separation by Duncan's multiple range test, $P=0.05$.

wHand thinning was done to remove fruit that were closer than $15 \mathrm{~cm}$ ( 6 inches). Hand thinning was expressed as the number of fruit removed per centimeter of limb crosssectional area.

Ns, $,{ }^{* \star *},{ }^{* \star *}$ Nonsignificant or significant at $P=0.001,0.00,0.05$, respectively. $\mathrm{L}$ and $\mathrm{Q}$ indicate a linear or quadratic response, respectively.

whereas Wilthin increased fruit diameter only at the highest rate. There was a treatment $\times$ variety interaction for fruit weight and fruit diameter. When these data were reanalyzed by variety it appears that the cause of the interaction was that 'Garnet Beauty' did not respond as much to early thinning as did 'Red Haven' (Table 2). Specifically, Wilthin did not increase fruit size on either variety. Endothall increased fruit weight and diameter at the $P=$ 0.001 level in 'Red Haven', whereas it had no influence on fruit weight and a lower significance level for diameter on 'Garnet Beauty'. ATS increased fruit size and diameter on both varieties but the effect was at a lower significance level for 'Garnet Beauty'.

1998 Experiment. Blossom thinning treatments in general reduced initial set and the hand thinning re- quired to reduce crop load to a commercially acceptable level (Table 3 ). When analyzed separately, Wilthin was without effect while ATS and endothall showed modest reductions in initial set and hand thinning requirements. Treatment effects on fruit size were barely significant, and this effect was due to the thinning effect of ATS. Fruit size on 'Red Haven' was larger than that of 'Garnet Beauty' (data not shown).

Table 2. Effect of Wilthin, ${ }^{\mathrm{z}}$ endothall, and ammonium thiosulfate (ATS) on fruit weight and fruit size of 'Garnet Beauty' and 'Red Haven' peaches. $1997(28.35 \mathrm{~g}=1.0 \mathrm{oz}, 2.54 \mathrm{~cm}=1.0$ inch $)$.

\begin{tabular}{|c|c|c|c|c|}
\hline $\begin{array}{l}\text { Treatment } \\
\text { (rate) }\end{array}$ & \multicolumn{2}{|c|}{ Garnet Beauty } & \multicolumn{2}{|c|}{ Red Haven } \\
\hline Control & 167 & 7.0 & 199 & 7.3 \\
\hline \multicolumn{5}{|l|}{ Wilthin $9.3 \mathrm{~L} \cdot \mathrm{ha}^{-1}+$} \\
\hline Regulaid surfactant $\left(1.2 \mathrm{~L} \cdot \mathrm{ha}^{-1}\right)$ & 183 & 7.2 & 206 & 7.5 \\
\hline Endothall $1.5 \mathrm{~L} \cdot \mathrm{ha}^{-1}$ & 196 & 7.4 & 281 & 8.3 \\
\hline ATS $37.4 \mathrm{~L} \cdot \mathrm{ha}^{-1}$ & 202 & 7.5 & 275 & 8.3 \\
\hline ATS $74.8 \mathrm{~L} \cdot \mathrm{ha}^{-1}$ & 211 & 7.5 & 309 & 8.6 \\
\hline \multicolumn{5}{|l|}{ Significance } \\
\hline Wilthin & NS & NS & NS & NS \\
\hline
\end{tabular}

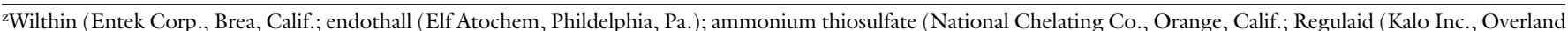
Park, Kan.).

y9.35 L.ha-1 $=1.0 \mathrm{gal} /$ acre.

Ns, $,{ }^{\star \star \star},{ }^{\star \star \star}$ Nonsignificant or significant at $P=0.001,0.01,0.05$, respectively. 
Table 3. Effect of Wilthin, ${ }^{\mathrm{z}}$ endothall, and ammonium thiosulfate (ATS) on fruit set, thinning and fruit size of 'Garnet Beauty' and 'Red Haven' peaches, $1998(28.35 \mathrm{~g}=1.0 \mathrm{oz}, 2.54 \mathrm{~cm}=1.0$ inch $)$.

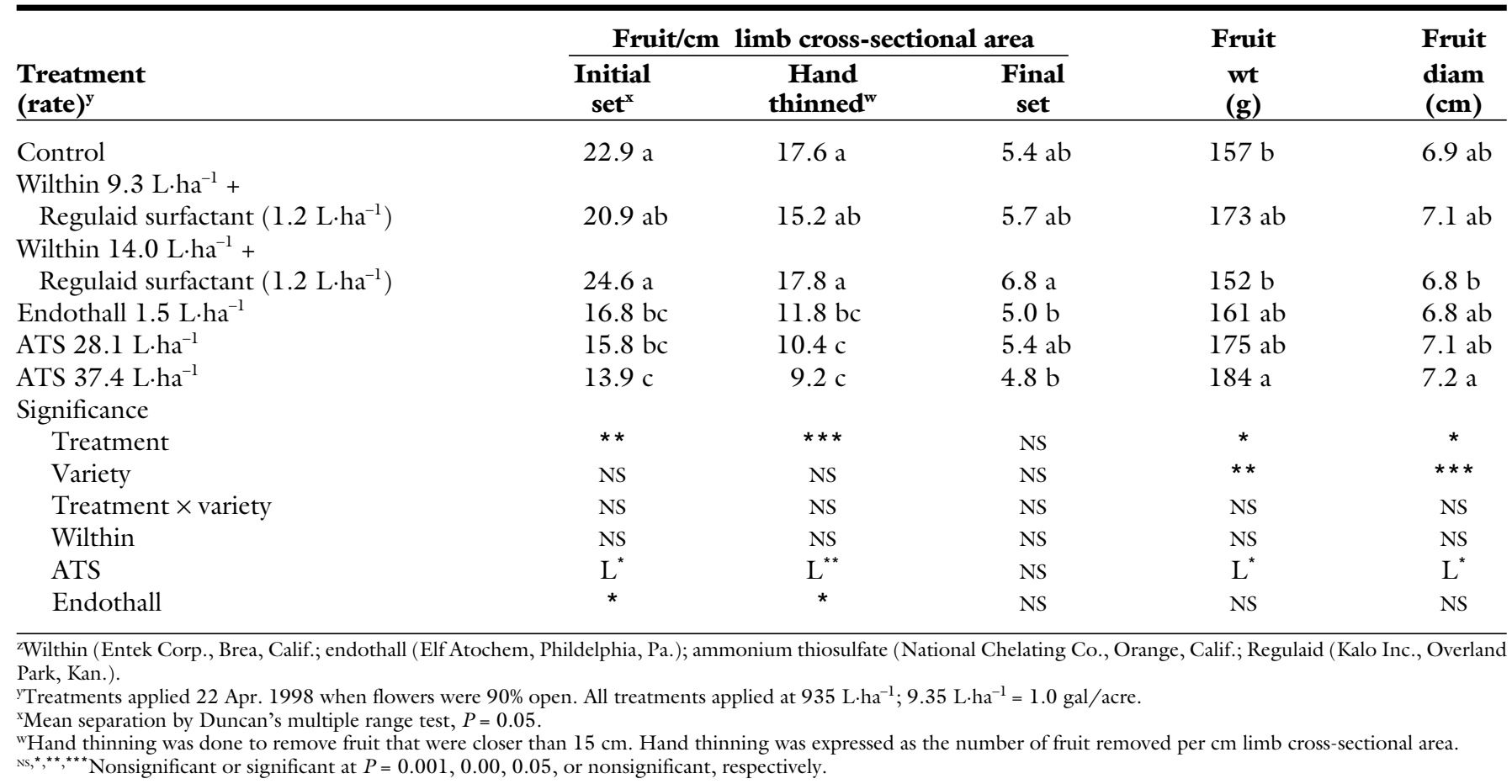

1999 Experiment. Blossom thinning treatments significantly reduced initial set and the number of fruit that were removed by hand thinning (Table 4 ). The response was highly significant for all treatments as well as linear and highly significant for Wilthin and ATS. Only ATS reduced final fruit set. Fruit weight and fruit diameter at harvest were increased by all blossom thinners.
ATS increased fruit weight and diameter most dramatically, endothall was intermediate, while Wilthin had the smallest effect, which was significant only at the highest rate used.

Table 4. Effect of Wilthin ${ }^{Z}$, endothall and ammonium thiosulfate (ATS) on fruit set, thinning and fruit size of 'Garnet Beauty' and 'Red Haven' peaches. $1999(28.35 \mathrm{~g}=1.0 \mathrm{oz}, 2.54 \mathrm{~cm}=1.0$ inch $)$.

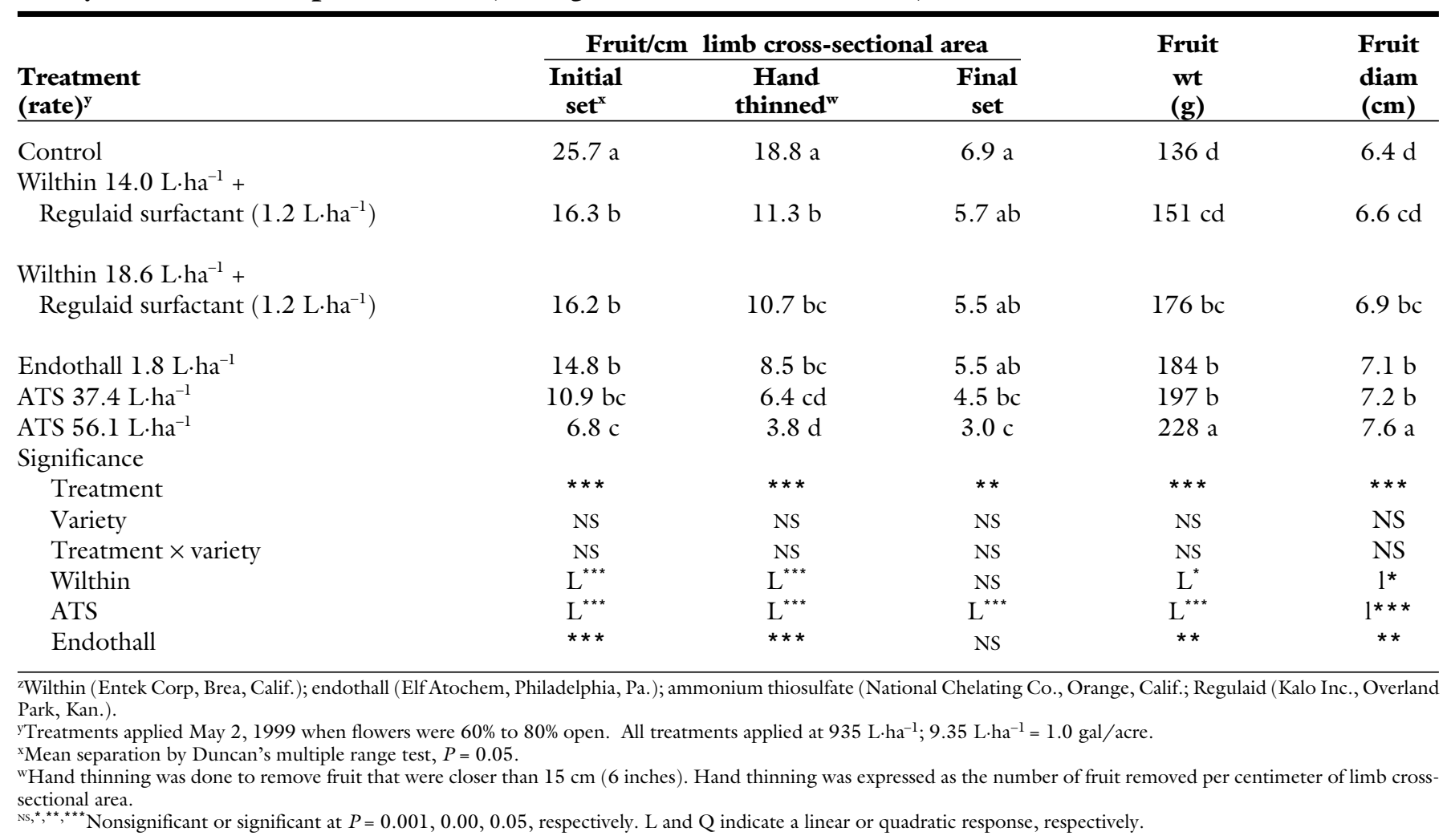




\section{Discussion}

One of the goals of this investigation was to identify concentrations of thinning chemicals that would consistently and effectively thin peaches. ATS caused excessive thinning, phytotoxicity, and shoot dieback in 1997. Part of the response was due to the higher rate used than reported in other investigations (Byers and Lyons, 1984, 1985). Another component was that the amount of spray deposited was increased in portions of the tree when the sprayer application was made into the wind. Rates were lowered in 1998 and applications were made under favorable thinning conditions. Insufficient thinning was achieved at the low rate of $28.1 \mathrm{~L} \cdot \mathrm{ha}^{-1}$. Concentrations were further adjusted in 1999 to 37.4 and 56.1 L.ha ${ }^{-1}$ and application was made again under favorable thinning conditions. Based on these results we believe that consistent and effective thinning with ATS can be achieved if between 35 and $45 \mathrm{~L} \cdot \mathrm{ha}^{-1}$ are applied in $935 \mathrm{~L} \cdot \mathrm{ha}^{-1}$ of spray volume. The highest rate of endothall used was 1.8 $\mathrm{L} \cdot \mathrm{ha}^{-1}$ in 1999, and that seemed to thin appropriately. Wilthin was the weakest thinner used, and even when applied at $18.6 \mathrm{~L} \cdot \mathrm{ha}^{-1}$, which is, in general, higher than previously used (Byers and Lyons, 1982) it was still a modest thinner at best.

The importance of blossom thinning to maximize fruit size at harvest has been recognized for many years (Havis, 1962). While thinning can be done if thinners are applied anywhere from pink to full bloom, the greatest response is when application are made near bloom (Byers and Lyons, 1982). Thinners act by interfering with ovule fertilization, either by preventing successful pollination or by disturbing pollen tube growth (Byers and Lyons, 1985). Results from this investigation suggest that timing of application may influence the thinner response. The best thinning results were obtained in
1999 when treatments were applied when blossoms were $65 \%$ to $80 \%$ open rather than near 95\% in 1997 and 1998. If flowers open over a several day period there may be ample opportunity for pollination and significant pollen tube growth of many flowers, before thinner applications are made at or near full bloom.

It was observed that blossom thinners did not thin uniformly on the tagged limbs. There were some areas of the limb that set a less than optimal number of fruit, thus fruit were spaced more than $15 \mathrm{~cm}$ apart, whereas other areas were set heavier and required more hand thinning. The reduction in final set by all treatments in 1997 and by ATS in 1999 documents that excessive thinning was done. Some hand thinning was also required on some excessively thinned limbs because there were areas where fruit were clustered.

Successful blossom thinning treatments resulted in a reduction in hand thinning of between $50 \%$ to $80 \%$. This reduction in hand thinning following blossom thinner use can be a significant savings in cost of labor and the need for labor, in an area where labor costs are high, if farm labor can be found. In general, it required about one hour to hand thin a control tree. The 264 trees / ha is an average density for the region. At $\$ 7.50 / \mathrm{h}$, the cost of hand thinning these trees would be $\$ 1982 /$ ha (\$802/acre). A 50\% to 80\% reduction in hand thinning would result in savings to the grower of $\$ 991$ to $\$ 1585 /$ ha $(\$ 401$ to $\$ 642 /$ acre $)$. Further, if there are few laborers available for this task, the thinning would be spread out over a longer time, resulting in further reductions in fruit size at harvest.

Some of the blossom thinning treatments reported in this investigation resulted in a reduction in yield, as expressed by number of fruit per limb cross sectional area. Fruit from these trees may pay a grower more money than higher yielding hand thinned control trees, because fruit on blossom thinned trees will be larger and higher prices are paid for larger fruit. There is little demand for a peach less than 6.4 $\mathrm{cm}(2.5$ inches $)$. The price paid for 7.0 to $7.6 \mathrm{~cm}$ (2.75 to 3.0 inches $)$ in diameter fruit may be twice that received for $6.4 \mathrm{~cm}$ fruit, and the demand in peak season for these larger fruit has been in recent years unlimited.

We believe that blossom thinning of peaches in New England is a practice that can be reliably and very profitably used by growers. Key components for success include selection of the proper rate of thinner to apply, apply the spray to mature plantings in $935 \mathrm{~L} \cdot \mathrm{ha}^{-1}$ of water in an accurately calibrated sprayer, and spray in appropriate weather before most flowers are pollinated, generally slightly before full bloom. In our estimation endothall and ATS hold the greatest potential as blossom thinners on peaches.

\section{Literature cited}

Byers, R.E. 1999. Effect of blossom-thinning chemicals on peach fruit set. J. Tree Fruit Prod. 2:59-78.

Byers, R.E. and C.G. Lyons. 1982. Flower bud removal with surfactants for peach thinning. HortScience 17:377-378.

Byers, R.E. and C.G. Lyons, Jr. 1984. Flower thinning of peach with desiccating chemicals. HortScience 19:545-546.

Byers, R.E. and C.G. Lyons, Jr. 1985. Peach flower thinning and possible sites of action for desiccating chemicals. J. Amer. Soc. Hort. Sci. 110:662-667.

Fallahi,E. 1997.Applications of endothallic acid, pelargonic acid, and hydrogen cyanamide for blossom thinning of apple and peach. HortTechnology 7:395-399.

Havis, A.L. 1962. Effect fruit thinning of 'Red Haven' peach. Proc. Amer. Soc. Hort. Sci. 80:172-176.

Lord, W.G. 1999. Restructuring the orchard business for survival. Proc. Mass. Fruit Growers’ Assn. 105:126-129. 